\title{
A study effects of yogic practice on respiratory system in apparently healthy volunteers at tertiary health care center
}

\author{
Moses Samuel
}

Associate professor study conducted in GEMS, Great Eastern Medical School And Hospital, At Srikakulam, Andhra Pradesh, INDIA. Email: drmosessamuel@gmail.com

\begin{abstract}
In the present study, the focus is on the effect of yoga (asanas and pranayama) on the lungs as pulmonary function has been identified as a long-term predictor for overall survival rates as well as a tool in general health assessment. Aims and Objectives: To study Effects of yogic practice on Respiratory system in apparently healthy volunteers at tertiary health care center. Methodology: This was a cross-sectional study carried out in the department of Physiology during the six month period i.e. January 2019 to June 2019 in the six month period the 50 apparently healthy volunteers with baseline comparable L.F.T were recruited for the study out of these 25 volunteers were not given any intervention (Non -Yogic group) and 25 given training of Yogasana and Pranayama by expert Yoga teacher (Yogic Group B) for 6 weeks duration. The PFT parameters like FVC (L/min), FEV1 (L/min), FEV1/FVC ratio (\%), FEF 25 75\% (L/min), PEFR (L/s), SVC (L/min), MVV (L/min). The statistical analysis was done by unpaired t-test and calculated by SPSS 19 version software. Result : FVC (L/min) was-4.02 \pm 0.54 and $2.98 \pm 0.34(\mathrm{P}<0.001, \mathrm{t}=5.58, \mathrm{df}=48)$; FEV1 (L/min)- $3.84 \pm 0.17$ and $2.82 \pm 0.27$ $(\mathrm{P}<0.05, \mathrm{t}=3.92, \mathrm{df}=48) ; \mathrm{FEV} 1 / \mathrm{FVC}$ ratio $(\%)$ was $98.29 \pm 3.78$ and $92.53 \pm 4.89(\mathrm{P}<0.001, \mathrm{t}=11.98, \mathrm{df}=48) ; \mathrm{FEF} 2575 \%$ $(\mathrm{L} / \mathrm{min})$ was $4.93 \pm 0.13$ and $3.53 \pm 1.45 \quad(\mathrm{P}<0.01, \mathrm{t}=4.52, \mathrm{df}=48) ; \quad \mathrm{PEFR}(\mathrm{L} / \mathrm{s})$ was $7.03 \pm 1.23$ and $4.92 \pm 2.56$ $(\mathrm{P}<0.005, \mathrm{t}=6.79, \mathrm{df}=48), \quad \mathrm{SVC}(\mathrm{L} / \mathrm{min})-3.84 \pm 0.25$ and $1.78 \pm 0.38 \quad(\mathrm{P}<0.001, \mathrm{t}=7.94, \mathrm{df}=48) ; \mathrm{MVV} \quad(\mathrm{L} / \mathrm{min}) \quad$ was 95.14 \pm 4.97 and $92.19 \pm 5.62(\mathrm{P}<0.001, \mathrm{t}=12.76, \mathrm{df}=48)$ Significantly higher in Yogic Group as Compared to Non Yogic Group volunteers. Conclusion: It can be concluded from our study that the lung function by various parameters of LFT showed there is significant improvement of lung function.
\end{abstract}

Key Word: yoga (asanas and pranayama), PFT (Pulmonary Function Test)

\section{Address for Correspondence}

Dr. Moses Samuel, Associate professor study conducted in GEMS, Great Eastern Medical School \& Hospital, At Srikakulam,

Andhra Pradesh, INDIA.

Email: drmosessamuel@gmail.com

Received Date: 02/09/2019 Revised Date: 11/10/2019 Accepted Date: 30/10/2019

DOI: https://doi.org/10.26611/1031512

This work is licensed under a Creative Commons Attribution-NonCommercial 4.0 International License. $(\boldsymbol{C c})$ EY-NC

\begin{tabular}{|l|l|}
\hline \multicolumn{2}{|c|}{ Access this article online } \\
\hline Quick Response Code: & Website: \\
\hline & www.medpulse.in \\
\hline & \\
\hline
\end{tabular}

\section{INTRODUCTION}

Physical activity in the form of Exercises if performed regularly, have a beneficial effect on the various systems of the body. The modality of exercise that is most beneficial and economic for masses has now become the topic of research. ${ }^{1}$ The conventional exercises (endurance exercises like walking, jogging, running, swimming, cycling, etc), which give stress on cardiovascular and respiratory systems and test the responses of these systems, are very popular. On the other hand, ancient yogic exercises which have been claimed to benefit human body on multiple fronts are also getting popularity all over the world. ${ }^{2}$ In the present study, the focus is on the effect of yoga (asanas and pranayama) on the lungs as pulmonary function has been identified as a long-term predictor for overall survival rates as well as a tool in general health assessment. ${ }^{3}$ yoga have been reported to improve the pulmonary functions to a great extent and it 
involve physical activity as well as breathing exercise. ${ }^{4,5}$ Hence we have studied the effectiveness of Yogasana and Pranayama for the improving the pulmonary function test

\section{METHODOLOGY}

This was a cross-sectional study carried out in the department of Physiology during the six month period i.e. January 2019 to June 2019 in the six month period the 50 apparently healthy volunteers with baseline comparable L.F.T were recruited for the study out of these 25 volunteers were not given any intervention (Non-Yogic group) and 25 given training of Yogasana and Pranayama by expert Yoga teacher (Yogic Group B) for 6 weeks duration. The PFT parameters like FVC (L/min), FEV1 (L/min), FEV1/FVC ratio (\%), FEF $25-75 \%$ (L/min), PEFR (L/s), SVC (L/min), MVV (L/min). Ethical approval was taken from Institutional ethical committee. The statistical analysis was done by unpaired t-test and calculated by SPSS 19 version software.

\section{RESULT}

Table 1: Distribution of the patients as per the age and sex

\begin{tabular}{cccc}
\hline & $\begin{array}{c}\text { Non-Yogic } \\
(\mathrm{n}=25)\end{array}$ & $\begin{array}{c}\text { Yogic } \\
(\mathrm{n}=\mathbf{2 5})\end{array}$ & $\mathrm{t}$-value and $\mathrm{p}$-value \\
\hline Age (Yrs.) & $31.45 \pm 3.98$ & $32.45 \pm 4.17$ & $\mathrm{t}=0.78, \mathrm{df}=49$, \\
$\mathrm{pex}$ & & & 0.05 \\
Male & 15 & 14 & $\mathrm{X}^{2}=0.34, \mathrm{df}=1$, \\
Female & 10 & 11 & $\mathrm{p}>0.05$
\end{tabular}

The age was comparable $31.45 \pm 3.98$ and $32.45 \pm 4.17$ $(\mathrm{t}=0.78, \mathrm{df}=49, \mathrm{p}>0.05)$; The ratio of male to female was $1.50: 1$ and 1.30: 1 was also comparable $\left(\mathrm{X}^{2}=0.34, \mathrm{df}=1\right.$, $\mathrm{p}>0.05)$.

Table 2: Distribution of the patients as per the PFT parameters

\begin{tabular}{|c|c|c|c|}
\hline $\begin{array}{c}\text { PFT } \\
\text { parameters }\end{array}$ & $\begin{array}{l}\text { Non-Yogic } \\
(n=25)\end{array}$ & $\begin{array}{l}\text { Yogic } \\
(n=25)\end{array}$ & $p$-value \\
\hline $\mathrm{FVC}(\mathrm{L} / \mathrm{min})$ & $2.98 \pm 0.34$ & $4.02 \pm 0.54$ & $P<0.001, t=5.58, d f=48$ \\
\hline $\begin{array}{l}\text { FEV1 } \\
\text { (L/min) }\end{array}$ & $2.82 \pm 0.27$ & $3.84 \pm 0.17$ & $P<0.05, t=3.92, d f=48$ \\
\hline $\begin{array}{l}\text { FEV1/FVC } \\
\text { ratio (\%) }\end{array}$ & $92.53 \pm 4.89$ & $98.29 \pm 3.78$ & $\mathrm{P}<0.001, \mathrm{t}=11.98, \mathrm{df}=48$ \\
\hline $\begin{array}{l}\text { FEF } 25-75 \% \\
\text { (L/min) }\end{array}$ & $3.53 \pm 1.45$ & $4.93 \pm 0.13$ & $P<0.01, t=4.52, d f=48$ \\
\hline $\operatorname{PEFR}(\mathrm{L} / \mathrm{s})$ & $4.92 \pm 2.56$ & $7.03 \pm 1.23$ & $P<0.005, t=6.79, d f=48$ \\
\hline SVC (L/min) & $1.78 \pm 0.38$ & $3.84 \pm 0.25$ & $P<0.001, t=7.94, d f=48$ \\
\hline $\begin{array}{l}\text { MVV } \\
\text { (L/min) }\end{array}$ & $92.19 \pm 5.62$ & $95.14 \pm 4.97$ & $\begin{array}{c}\mathrm{P}<0.001, \mathrm{t}=12.76 \\
\mathrm{df}=48\end{array}$ \\
\hline
\end{tabular}

FVC $\quad(\mathrm{L} / \mathrm{min}) \quad$ was $-4.02 \pm 0.54$ and $2.98 \pm 0.34$ $(\mathrm{P}<0.001, \mathrm{t}=5.58, \mathrm{df}=48)$; FEV1 (L/min)- $3.84 \pm 0.17$ and $2.82 \pm 0.27(\mathrm{P}<0.05, \mathrm{t}=3.92, \mathrm{df}=48) ; \mathrm{FEV} 1 / \mathrm{FVC}$ ratio $(\%)$ was $\quad 98.29 \pm 3.78 \quad$ and $92.53 \pm 4.89$ $(\mathrm{P}<0.001, \mathrm{t}=11.98, \mathrm{df}=48) ; \quad \mathrm{FEF} \quad 25-75 \% \quad(\mathrm{~L} / \mathrm{min})$ was $4.93 \pm 0.13$ and $3.53 \pm 1.45(\mathrm{P}<0.01, \mathrm{t}=4.52, \mathrm{df}=48)$; PEFR $(\mathrm{L} / \mathrm{s})$ was $7.03 \pm 1.23$ and $4.92 \pm 2.56 \quad(\mathrm{P}<0.005, \mathrm{t}=6.79$, $\mathrm{df}=48), \quad \mathrm{SVC} \quad(\mathrm{L} / \mathrm{min})-\quad 3.84 \pm 0.25$ and $1.78 \pm 0.38$ $(\mathrm{P}<0.001, \mathrm{t}=7.94, \mathrm{df}=48) ; \mathrm{MVV}(\mathrm{L} / \mathrm{min})$ was $95.14 \pm 4.97$ and 92.19 $\pm 5.62(\mathrm{P}<0.001, \mathrm{t}=12.76, \mathrm{df}=48)$ Significantly higher in Yogic Group as Compared to Non Yogic Group volunteers.

\section{DISCUSSION}

Yogic Asanas and Pranayama have been shown to reduce the resting respiratory rate. Furthermore, they increase timed vital capacity, and maximal voluntary ventilation, breath holding time, maximal inspiratory pressure and maximal expiratory pressure. ${ }^{6}$ Pranayama is an important component of Yoga training. Pranayama (controlled breathing exercise) improves the air way reactivity in the asthmatic individuals. It was noted that high frequency breathing exercise resulted in more than 10 fold increase in expired minute ventilation. ${ }^{7}$ Many reports supported the beneficial effect of longterm Yoga training on pulmonary functions. ${ }^{5,8}$ It has been reported that regular Yoga practice resulted in decrease in resting respiratory rate. ${ }^{9}$ It has also been reported that short term Yoga practice resulted in significant improvement in $\mathrm{BHT}^{10,11}$ and MVV. ${ }^{12}$ In our study we have seen that The age was comparable $31.45 \pm 3.98$ and $32.45 \pm 4.17(\mathrm{t}=0.78, \mathrm{df}=49$, $\mathrm{p}>0.05$ ); The ratio of male to female was $1.50: 1$ and 1.30: 1 was also comparable $\left(\mathrm{X}^{2}=0.34, \mathrm{df}=1, \mathrm{p}>0.05\right)$. FVC $(\mathrm{L} / \mathrm{min})$ was$4.02 \pm 0.54$ and $2.98 \pm 0.34(\mathrm{P}<0.001, \mathrm{t}=5.58, \mathrm{df}=48) ; \mathrm{FEV} 1(\mathrm{~L} /$ $\min )-3.84 \pm 0.17$ and $2.82 \pm 0.2(\mathrm{P}<0.05, \mathrm{t}=3.92, \mathrm{df}=48)$;

FEV1/FVC ratio (\%) was $98.29 \pm 3.78$ and $92.53 \pm 4.89$ $(\mathrm{P}<0.001, \mathrm{t}=11.98, \mathrm{df}=48) ; \quad \mathrm{FEF} \quad 25-75 \% \quad(\mathrm{~L} / \mathrm{min})$ was $4.93 \pm 0.13$ and $3.53 \pm 1.45(\mathrm{P}<0.01, \mathrm{t}=4.52, \mathrm{df}=48)$; PEFR $(\mathrm{L} / \mathrm{s})$ was $7.03 \pm 1.23$ and $4.92 \pm 2.56 \quad(\mathrm{P}<0.005, \mathrm{t}=6.79$, $\mathrm{df}=48), \quad \mathrm{SVC} \quad(\mathrm{L} / \mathrm{min})-\quad 3.84 \pm 0.25$ and $1.78 \pm 0.38$ $(\mathrm{P}<0.001, \mathrm{t}=7.94, \mathrm{df}=48) ; \mathrm{MVV}(\mathrm{L} / \mathrm{min})$ was $95.14 \pm 4.97$ and 92.19 $\pm 5.62(\mathrm{P}<0.001, \mathrm{t}=12.76, \mathrm{df}=48)$ Significantly higher in Yogic Group as Compared to Non Yogic Group volunteers. These findings are similar to Kuppuswamy et $a l^{13}$ they found A significant $(\mathrm{P}<0.05)$ improvement in all pulmonary function parameters; FVC, FEV1, FEV1/FVC ratio, FEF $25 \%-75 \%$ and PEFR was seen in the Bhr.P group than the control group adolescents. Slow vital capacity (SVC) and Maximum Voluntary Volume (MVV) also showed significant improvement in the prāṇāyāma group.

\section{CONCLUSION}

It can be concluded from our study that the lung function by various parameters of LFT showed there is significant improvement of lung function. 


\section{REFERENCES}

1. Shimamoto H, Adachi Y, Takahashi M, Tanaka K. Low impact aerobic dance as useful exercise mode for reducing body mass in mildly obese middle aged women. Appl Human Sci. 1998; 17: 109-14.

2. Khalsa SB. Yoga as a therapeutic intervention: A bibliometric analysis of published research studies. Indian J PhysiolPharmacol. 2004; 48: 269-85.

3. Schunemann HJ, Dorn J, Grant BJ, Winkelstein W, Jr, Trevisan M. Pulmonary Function is a long-term predictor of mortality in the general population: 29-year follow-up of the buffalo health study. Chest. 2000; 118: 656-64. 7

4. Prakash S, Meshram S, Ramtekkar U. Atheletes, yogis and individuals with sedentary lifestyle; Do their lung functions differ. Indian J PhysiolPharmacol. 2007; 51: 76-80.

5. Pherwani AV, Desai AG, Solepure AB. A study of pulmonary functions of competitive swimmers. Indian $\mathbf{J}$ PhysiolPharmacol. 1989; 33: 228-32.

6. Gopal KS, Bhatnagar OP, Subramanian N, Nishith SD. Effect of Yogasanas and Pranayamas on blood pressure, pulse rate and some respiratory function. Indian $\mathbf{J}$ PhysiolPharmacol. 1973;73(3):273-6.

7. Joshi LN, Joshi VD, Ghokale LV. Effect of short term Pranayama practice on breathing rate and ventilatory function of lung. Indian J PhysiolPharmacol. 1992; 36(2):105-8.

8. Frostell C, Pande JN, Hedenstierna G. Effects of highfrequency breathing on pulmonary ventilation and gas exchange. J Appl Physiol. 1983; 55: 1854-61.

9. Udupa KN, Singh RH, Settiwar RM. Studies on the effect of some Yogic breathing exercises (Pranayamas) in normal persons. Indian J Med Res. 1975; 63: 1062-5.

10. 9. Doijad VP, Surdi AD. Effect of short term Yoga practice on cardio-respiratory fitness parameters. IJBMS. 2012; 2(6):286-90.

11. Ankad RB, Ankad BS, Herur A, Patil S, Chinagudi S, Shashikala GV. Effect of short term Pranayama and meditation on respiratory parameters in healthy individuals. Int J Collab Res Intern Med Public Health. 2011; 3(6):429-37.

12. Mullur L, Bagali S, Khodnapur JP, Aithala M. Role of short term Yoga on pulmonary functions of young and middle aged healthy individuals. IJBAR. 2012; 3(4):2525.

13. Doijad VP, Surdi AD. Effect of short term Yoga practice on pulmonary function tests. Indian J Basic Appl Med Res. 2012; 3(1):226-30

14. Kuppusamy M, Dilara K, Ravishankar P, Julius A. Effect of bhrāmarīPrān. āyāma practice on pulmonary function in healthy adolescents: A randomized control study. Ancient Sci Life 2017; 36: 196-9.

\section{Source of Support: None Declared Conflict of Interest: None Declared}

Policy for Articles with Open Access:

Authors who publish with MedPulse International Journal of Physiology (Print ISSN: 2550-7613) (Online ISSN: 2636-4565) agree to the following terms: Authors retain copyright and grant the journal right of first publication with the work simultaneously licensed under a Creative Commons Attribution License that allows others to share the work with an acknowledgement of the work's authorship and initial publication in this journal.

Authors are permitted and encouraged to post links to their work online (e.g., in institutional repositories or on their website) prior to and during the submission process, as it can lead to productive exchanges, as well as earlier and greater citation of published work. 